This item was submitted to Loughborough's Research Repository by the author.

Items in Figshare are protected by copyright, with all rights reserved, unless otherwise indicated.

\title{
Exploring expatriate adjustment through identity perspective
}

PLEASE CITE THE PUBLISHED VERSION

https://doi.org/10.1016/j.ibusrev.2020.101667

PUBLISHER

Elsevier

VERSION

AM (Accepted Manuscript)

PUBLISHER STATEMENT

This paper was accepted for publication in the journal International Business Review and the definitive published version is available at https://doi.org/10.1016/j.ibusrev.2020.101667.

\section{LICENCE}

CC BY-NC-ND 4.0

\section{REPOSITORY RECORD}

Peltokorpi, Vesa, and Ling Eleanor Zhang. 2020. "Exploring Expatriate Adjustment Through Identity Perspective". Loughborough University. https://hdl.handle.net/2134/12937517.v1. 


\title{
Exploring Expatriate Adjustment through Identity Perspective
}

\begin{abstract}
This study reveals multifaceted identities experienced by corporate expatriates and how these identities are related to expatriate host country work and non-work adjustment. Specifically, we take a symbolic interactionism-based identity theory perspective and examine qualitative data from 73 corporate expatriates in China and Japan, revealing an expatriate identity (i.e., identification with being a manager and a foreigner), and a cultural identity (i.e., identification with home and host country cultures) which through identity stability/change are related to the mode and degree of expatriate work and non-work adjustment. Our findings suggest that these identities explain how corporate expatriates shape their new environment to their preferences, instead of adjusting to it.
\end{abstract}

Keywords: expatriate identity; cultural identity; cross-cultural adjustment 


\section{Introduction}

The accelerating globalization has led multinational corporations (MNCs) to continue to rely on expatriates to increase their competitiveness in the global marketplace (Kraimer, Bolino, \& Mead, 2016). Despite increasing research on expatriate management (for reviews, see Kraimer et al., 2016; Takeuchi, 2010), many important questions on expatriate identities and host country adjustment still remain. In particular, scholars have recently called for novel perspectives of the identities of expatriates (Adams \& van de Vijver, 2015) and research on how specific identities (Kraimer et al., 2016) are related to expatriate adjustment. However, because of the exclusive focus on cultural identity (Adams \& van de Vijver, 2015) and dominance stressor-strain based accounts of adjustment (Ren, Shaffer, Harrison, Fu, \& Fodchuk, 2014) in prior research, very little is known about the multifaceted identities of expatriates, their relation to adjustment, and how identities explain why expatriates proactively seek to influence rather than reactively adapt to their new environments in host countries.

When the identities of expatriates have received attention in research, cultural identity has been the main, if not the only, type of identity considered (Kohonen, 2008; Näsholm, 2012; Scurry, Rodriquez, \& Bailouni, 2013). We agree that cultural identity - a self-concept derived from membership of a specific national group (Sussman, 2000) - is relevant to understanding the experience of expatriates. At the same time, the focus on cultural identity has prevented scholars from considering other identities that could be equally, if not more, salient and important in expatriate adjustment. We propose that essential, but often neglected, identities are associated with identifying (and to some extent being identified) as an expatriate in work and non-work settings. Thus, the main purpose of this study is to explore if, and in what way, the identities of expatriates relate to their adjustment in host countries. More specifically, we use the symbolic 
interactionism-based identity theory (Burke, 1991; Stryker, 1980) and interview data from 73 corporate expatriates in China and Japan to explore if, and in what way, the identities of expatriates relate to their work and non-work adjustment in these host countries. In line with Harrison, Shaffer, and Bhaskar-Shrinivas (2004: 203), we define corporate expatriates in this study as "employees of business organizations, who are sent overseas on a temporary basis to complete a time-based task or accomplish an organizational goal." The identity theory is useful in our exploration, because it captures how the social environment influences self-definition and how that self-definition in turn influences behaviors (via identity-consistent behaviors; Stryker \& Burke, 2000). The theory is also in line with our interest in understanding how the identities of expatriates influence how they perceive themselves in that role, and how they engage with their environment.

This study seeks to contribute to expatriate research in four ways. First, by using the identity theory and interview data from expatriates in two host countries, we demonstrate how roles and context are related to both degree and mode of adjustment through identity processes that include but go beyond prior studies on cultural identities (Kohonen, 2004; Näsholm, 2012; Scurry et al., 2013). We do this by focusing on the multifaceted identities of expatriates and linking them to host country adjustment. Second, we provide a novel identity-theory-based perspective on expatriate adjustment. Despite its relevance to and potential for understanding the expatriate experience, to date only two studies have used the symbolic interactionism-based identity theory (Burke, 1991; Stryker, 1980) to study expatriate spouse adjustment (Shaffer \& Harrison, 2001) and repatriate turnover (Kraimer, Shaffer, Harrison, \& Ren, 2012). Providing a different perspective, we reveal multifaceted identities as experienced by expatriates during international assignments. Third, we explore how these identities are related to expatriate 
adjustment. Despite increasing research on expatriate adjustment, little is known about the identity-adjustment linkage; this is partly because changes in cultural identities have been equated with adjustment (e.g., Mao \& Shen, 2015). However, because self-identities manifest themselves in concert with the context settings (Burke \& Stets, 2009), our findings suggest that lengthy experiences in host countries do not necessarily produce changes in cultural identity and that other identities may provide a more comprehensive perspective on expatriate adjustment. Fourth, going beyond the dominant reactive accounts of expatriate host country adjustment (Black, Mendenhall, \& Oddou, 1991; Black \& Stephens, 1989), we use the identity theory to demonstrate that expatriates can proactively change their new environment to fit their own preferences.

\section{Conceptual Framework}

\subsection{Expatriate Adjustment}

Expatriate research is still predominately based on the stressor-strain perspective (Black et al., 1991) of the degree of cross-cultural adjustment (Black \& Stephens, 1989) formulated three decades ago (Takeuchi, 2010). Although Black et al. (1991: 307) suggested - "we must consider both mode of adjustment and degree of adjustment" - most studies have examined only the degree of adjustment (Kraimer et al., 2016). The mode of adjustment refers to the manner individuals adapt to the environment or seek to change the environment to correspond to their own needs and abilities (Nicolson, 1984), and the degree of adjustment to the psychological comfortability and familiarity of expatriates with different aspects of a foreign culture (Black et al., 1991). The degree of adjustment consists of three interrelated facets: (1) general adjustment is the degree of psychological comfort with various aspects of the environment in the host country; (2) interaction adjustment is the degree of psychological comfort in interacting with 
locals in work and non-work settings; and (3) work adjustment is the degree of psychological comfort with specific expectations and standards in the work context. Bell and Harrison (1996) argued that the interaction adjustment is the most fundamental dimension of the three, because both work and general adjustment are influenced by the interaction with locals. In terms of predictors of the three adjustment facets that are achieved through uncertainty reduction and change, Black et al. (1991) developed a conceptual framework that combined individual and environmental factors, and cultural differences. In line with Black et al. (1991), scholars have largely described adjustment as reduction of acculturative stress or a person-environment (P-E) fit that expatriates achieve by learning and exhibiting culturally appropriate behaviors to fit in with the host country culture (Maertz, Hassan, \& Magnusson, 2009).

The conventional rationale by Black and associates is apparent in research on expatriate adjustment in China and Japan. Indeed, scholars have often conceptualized and operationalized adjustment through the three facets and provided reactive accounts of expatriate adjustment in China (e.g., Armstrong \& Li, 2017; Selmer, 1999) and Japan (e.g., Black \& Gregersen, 1991; Peltokorpi \& Froese, 2012). For instance, a study in China shows that expatriates adjust better when their learning styles were congruent with the demands of the host culture (Armstrong \& Li, 2017). A study in Japan, in turn, suggests positive relationships between expatriates' personality traits of open mindedness and interaction adjustment, emotional stability and cultural empathy and general adjustment, and social initiative and work adjustment (Peltokorpi \& Froese, 2012). The conventional rationale used in expatriate studies in China and Japan is consistent with the bulk of research on expatriate cross-cultural adjustment (see Kraimer et al., 2016; Takeuchi, 2010). 
These dominant perspectives, however, have not remained unchallenged. For instance, Ren et al. (2014: 204) stated that research is still predominately based on reactive accounts of expatriates' exposure to demands and adjustment; that is, "the environment impinges on the person $(\mathrm{E} \rightarrow \mathrm{P})$, who has to adapt." Thus, little is known about how expatriates influence their environments $(\mathrm{P} \rightarrow \mathrm{E})$. Haslberger, Brewster, and Hippler (2013), in turn, argued for the need to consider affective, behavioral, and cognitive dimensions of adjustment and multiple features of the context for a more agentic account of expatriate adjustment. Furthermore, Maertz, Takeuchi, and Chen (2016) conceptualized that change in adjustment criteria occurs in and around discrete adjustment episodes. Focusing on episodes of expatriate-local interaction, their model suggests that adjustment is not a continuous progression of change as quantitative studies suggest, but rather as interaction episodes-meaningful discrete experiences with an associated time and place. Molinsky (2007) suggested that identity conflict is experienced when the norms for certain interactions in host countries make it impossible for non-locals to act in culturally appropriate ways and in ways that are consistent with their internalized system of values from their home countries. The more unfamiliar and discrepant the new cultural norms are, the more likely it is that some aspect of these norms will conflict with an individual's identity and values. Although expatriates can adjust better to host countries by learning/imitating behaviors that are appropriate in the host culture, they can experience identity conflict by behaving in ways that are incongruent with their core values. Furthermore, a recent interview study on 12 corporate expatriates and 16 self-initiated expatriates from Germany in South Korea suggests that ethnocentric corporate expatriates neither want to nor have to adjust their work-life preferences to prevailing local practices (Bader, Froese, \& Kraeh, 2018). 
The alternative theorizing and empirical evidence challenge the dominant reactive perspectives by suggesting that expatriates can experience identity conflicts and proactively shape their environment to fit their own preferences. Indeed, expatriation creates situations in which individuals are likely to reflect on their identity (Kraimer et al., 2012). However, there is very little research on the identities of expatriates, how identities influence their host country adjustment, and whether expatriates seek to either adjust to or change their new environments in host countries. We suggest that the symbolic interactionism-based identity theory (Burke, 1991; Stryker, 1980) helps with expanding our understanding of expatriates' identities in host countries, and how these identities interact with their sense of self and their subsequent attitudes, behaviors, and adjustment. We elaborate on these issues in the next section.

\subsection{Identity Theory}

Rooted in symbolic interactionism (Mead, 1934), two closely related perspectives of identity theory (Burke, 1991; Stryker, 1980) describe the reciprocal relations between behavior and social environment. Based on these relations, individuals are motivated to engage in identityconsistent behaviors. In this theory, an identity is described as a set of self-relevant meanings held as standards for the identity in question (Burke, 1991). Specifically, identity consists of meanings attached to roles that individuals occupy in the social structure (i.e., role identities), groups they identify with and belong to (i.e., group identities), and unique ways in which they see themselves (i.e., person identities) (Burke \& Stets, 2009).

Applied to our study, identity is understood as a set of meanings that define individuals in specific roles (e.g., an expatriate manager of a foreign subsidiary), as members of specific groups (e.g., expatriates in China), and as individuals having specific characteristics that make them unique or distinct from others (e.g., an American expatriate in China). Identities help to organize 
an individual's place in interactions, to guide behavior, facilitate the development of stable relationships, and make social interaction possible (Burke, 1991; Burke \& Stets, 2009). This is all within the context of a social structure (Burke \& Stets, 2009; Stryker \& Burke, 2000). Meanings are individuals' responses when they reflect on themselves in a role, social, or person identity (Burke \& Stets, 2009). Expatriates can therefore think of themselves as a headquarters' change agent in terms of their work roles; a foreigner as a member of expatriate groups; and as for example - an American in terms of being a unique individual in a particular context. Taking a different approach, scholars have suggested that MNCs assign expatriates to foreign subsidiaries for the purposes of control, coordination, and managerial development (Edström \& Galbraith, 1977; Harzing, 2001), and that expatriates are expected to fulfill various different and often conflicting roles and responsibilities in foreign subsidiaries (Bartlett \& Ghoshal, 1992; Vora, Kostova, \& Roth, 2007).

While individuals can have multiple identities that are arranged hierarchically in an identity salience structure, not all of them are equally important for an individual's self-conception - more salient identities have a greater probability of being brought into situations through verbal and behavioral action (Burke, 1980). Because more salient identities have a greater likelihood of being brought into situations through verbal and behavioral action, identity salience is a behavioral indicator that presents an agentic aspect of identity in social action (Burke, 1991; Burke \& Stets, 2009). The most salient identities provide overarching schemas through which individuals interpret and respond to life events; these schemas also guide behaviors in novel and uncertain situations (Reitz \& Murtan, 1994). Individuals can reinforce their salient identities through identity verification by engaging in behaviors designed to match others' perceptions of them with how they perceive themselves (Burke \& Stets, 2009). If the 
feedback received from others is consistent with an individual's identity standard, his or her identity is reinforced and maintained. When input meanings are not congruent with the identity standard, disruptions to the identity process can occur (Stryker \& Burke, 2000). The identity system responds to these disruptions such that the individual tries to modify the behaviors or resources of others in the social setting, so they will reflect his or her identity standard. It should be noted that identity disruptions are not necessarily negative - identity disruption of being an expatriate can be one mechanism by which the self of the expatriate 'opens up' to alternative identities, such as an identity associated with the foreign subsidiary, the local culture, and/or the local employees, all of which can be related to adjustment.

To date, the use of identity theory in understanding the expatriate experience is limited, but when used, it has provided interesting insights. In a study on expatriate spouse adjustment, Shaffer and Harrison (2001) argued that disruptions or changes in the identity process (leading to identity reformation) can occur when individuals enter new cultures or adopt new roles. In such situations, an individual's perceived meanings are incongruent with his or her identity standard. Such discrepancies between the individual's identity standard and the environmental inputs result in distress. Reducing this distress requires changing one's behaviors. In a conceptual paper, Lazarova, Westman, and Shaffer (2010) saw value in considering identities associated with the work-family interfaces expatriates have, arguing that related role identities (e.g., employee and partners/parents) can be simultaneously salient. In a study on repatriate turnover, Kraimer et al. (2012) proposed that expatriates adapting to international assignments go through sense-making processes that require them to revise their role identity to respond effectively to the host country context. The misfit with the host country context can threaten expatriates' identity and create identity strain. The misfit occurs because the transition requires an expatriate to adapt to new 
work/living contexts that are different from his or her home country. Importantly, providing evidence of cultural identity change, Kraimer et al.'s study suggests that the amount of strain repatriates experience can be considerable due to their international employee identity - "the degree to which an individual's role as an expatriate has become central to her/his self-concept" (2012: 401). Finally, Adams and van de Vijver (2017) conceptualized that social relationships are important for how expatriates define themselves, as they help in defining roles that give meaning to the expatriates' lives.

While not using the identity theory, conceptual and empirical works also suggest that certain identities and identity disruptions could influence expatriate adjustment. By using 21 narrative interviews, Kohonen (2008) distinguished three expatriate cultural identity types: identity shifters, identity balancers, and identity non-shifters. In another study based on 20 narrative interviews, Näsholm (2012) found that cultural identities of expatriates with several assignments were constructed differently based on the length of assignments, career stage, work and organizational identification, and their home and host country. In contrast to our focus on corporate expatriates, another narrative interview study with 20 self-initiated expatriates in Qatar suggests that expatriates engage in agentic efforts to challenge barriers and constraints to their mobility and opportunity in a highly regulated context (Scurry et al., 2013). In turn, a study on 260 Belgian and Israelian corporate and self-initiated expatriates in the USA finds that those expatriates who consider themselves to have cosmopolitan identities (i.e., "citizens of the world)" adjust better to host countries (Grinstein \& Wathieu, 2012). However, in the long run, non-cosmopolitan expatriates adjusted better while cosmopolitans retreat into a global lifestyle. Mao and Shen (2015) suggested that expatriates' social networks in host countries can provide the impetus for cultural identity change. Being part of a close-knit expatriate network makes it 
less likely for expatriates to develop host country cultural identity due to the reduced need and opportunity to acquire cultural information and interact with locals. In contrast, extensive social networks with locals that help expatriates cope with acculturation stress may trigger reflections about an individual's own cultural values and assumptions, leading to the adoption of new cultural values and assumptions, and a change in expatriates' cultural identity. While having strong social networks with locals and host country identity facilitates expatriate adjustment, strong home country identity is negatively related to expatriate adjustment due to a lack of embeddedness in the host country culture (Mao \& Shen, 2015).

\subsection{Summary and Research Question}

Despite the possible multifaceted nature of identities experienced by expatriates during their assignments abroad, the focus in research to date has been either on work role identity, or cultural identity. To partially fill this gap in research, we use identity theory and interview data to distinguish possible multifaceted expatriate identities and their relation to expatriate adjustment. Identity theory suggests that people adopt role-based identities due to their social interactions with other people in the social network in which their role is embedded (Burke \& Stets, 2009; Stryker \& Burke, 2000). From the identity perspective, expatriates who interact mainly with other expatriates tend to have a more coherent identity than expatriates who interact primarily with locals (Mao \& Shen, 2015). That is, by interacting mainly with people who are similar to themselves in terms of ethnicity and work identity, expatriates can be confronted less with the question of who they are and what they are doing in a new country. In contrast, through frequent interactions with locals, expatriates are more likely to experience identity conflicts and identity transformation. Diverse work roles can also present competing or conflicting expectations for expatriates. For instance, expatriates can face conflicting expectations from local and global 
stakeholders. Because individuals can have multiple identities that are brought into situations through verbal and behavioral action (Burke \& Stets, 2009), this study seeks to answer to the research question: In what ways do the multifaceted identities of expatriates relate to their adjustment in the host countries?

\section{Method}

\subsection{Research Design and Settings}

We conducted a qualitative study that can be considered as an appropriate approach, given the need to develop an in-depth understanding of a relatively unexplored area (Birkinshaw, Brannen, \& Tung, 2011). Qualitative research is also particularly well-suited to the complex, contextual nature of this phenomenon (Edmondson \& McManus, 2007).

We conducted this study with expatriates from four Nordic countries (Finland, Denmark, Norway, and Sweden) in China and Japan because these countries are sufficiently different from the Nordic countries in terms of cultural values (Hofstede, 2001) and challenging destinations for expatriates (Guo, Rammal, Benson, Zhu, \& Dowling, 2018; Stahl \& Caligiuri, 2005). These are important conditions for exploring identity disruptions and their influence on adjustment. At the same time, the four Nordic countries have relatively similar cultural values, and China and Japan sufficiently different cultural values to detect possible differences among expatriates in these two host countries (Hofstede, 2001). In addition, the Nordic expatriates in China and Japan are likely to face various challenges relevant to our research question. For instance, there is an interesting contradiction between the elite status of being a Western corporate expatriate and being part of a minority (i.e., Nordic expatriates). At the same time, Nordic expatriates can have a different status among locals than expatriates from larger and more well-known Western countries (e.g., the USA) on which most prior research on expatriates has focused (Kraimer et al., 2016). Most 
Nordic expatriates also stand out as different in their physical appearance to locals in China and Japan, which can influence expatriate-local interactions, expatriate adjustment (Olsen \& Martins, 2009), and expatriate identities. Ingroup-outgroup categorization is also argued and shown to be more prevalent in collective countries such as China and Japan (Brewer \& Yuki, 2007; Triandis, 1989), which can influence the entities of expatriates. Finally, the focus on Nordic expatriates in China and Japan presents important advantages to our backgrounds as researchers (i.e., Nordic/ East Asian ethnicity and extensive experience of living in China, Japan, and Nordic countries). The experience of the researchers and their ability to understand the phenomenon studied is an important advantage in capturing relevant data and making sense of it (Morgan \& Smircich, 1980).

\subsection{Data Collection}

We conducted face-to-face interviews with 73 corporate expatriates in China and Japan between 2010 and 2014, largely in the workplace, and in an area where interviewees could not be overheard (see Table 1 for more information). The contact details of all these expatriates were obtained through Chambers of Commerce, Internet searches, and snowballing. We conducted these interviews gradually for several reasons: both authors were based in these host countries; expatriates often postponed interviews due to urgent business matters; and because the authors wished to gain additional information in informal settings. For instance, the first author met 12 expatriates after the interview in less formal settings through which additional information could be obtained. In total, we conducted semi-structured interviews with 27 corporate expatriates in Beijing, China (12 Finnish, 2 Swedish) and 45 expatriates in Osaka and Tokyo in Japan (8 Finnish, 13 Danish, 9 Norwegian, 15 Swedish). In line with prior research in China (Selmer, 
2004) and Japan (Stahl \& Caligiuri, 2005), several interviewed expatriates have lived in these host countries for more than five years.

With permission of the interviewees, all interviews (average length, 66 minutes) were digitally recorded at full length. In line with standard procedures (Kvale \& Brinkmann, 2015), we organized interview protocols into two sections (see the Appendix for guiding questions). All interviews started with a brief collection of descriptive data about the expatriates and the foreign subsidiaries which employed them and continued with open-ended questions that focused on expatriates' identity, identity change, and adjustment. Often, expatriates provided retrospective accounts of their experiences in China and Japan. In line with Fielding (1993), we followed the interviewed expatriates' lead while controlling the main areas of interests. We asked follow-up questions and asked the interviewees to elaborate on their answers when possible. In China, all interviews, except one held in Finnish, were conducted in English. In Japan, all expatriates from Finland were interviewed in Finnish, and others in English. In line with the usually high level of general English proficiency in Nordic countries, all interviewed expatriates were proficient in the language. We also wrote up field notes regarding the interviewees and other relevant matters such as the foreign subsidiaries visited. All interviews in Finnish were transcribed and translated verbatim by us (the coauthors/interviewers) and all interviews in English were transcribed by two research assistants proficient in English using original expressions and phrases (in Chinese or Japanese) to retain the original meaning (one research assistant in China and one research assistant in Japan). We double-checked the quality of the interviews transcribed by research assistants and found no significant differences between recorded interviews and interview transcripts. In total, we had 763,616 English words in our transcripts (219,959 in China, 543,657 in Japan). 
Insert Table 1 About Here

\subsection{Data Analysis}

Our analysis followed abductive reasoning, which "assigns primacy to the empirical world, but in the service of theorizing" (Van Maanen, Sorensen, \& Mitchell, 2007: 1149). Rooted in pragmatism (Pierce, 1903), abduction is the middle ground between deductive and inductive modes of reasoning (Van Maanen et al., 2007). Accordingly, we developed our theoretical ideas alongside increasingly detailed analysis of our data and allowed existing literature to inform our coding. Our analysis was supported by the qualitative data analysis computer software NVivo 8.

To avoid losing any relevant information, we first coded all data into broad categories covering all topics that related to identity and adjustment. We then identified and organized the data into four identity categories: manager identity, foreigner identity, national identity, and host country identity. Guided by the abductive approach, we chose these themes on empirical and theoretical grounds. In line with the identity theory that meaningful identities are invoked in a variety of situations (e.g., Stryker, 1980), our data showed the relevance of the above identities to expatriates' experiences in China and Japan. We defined/coded as manager identity the instances in which the data suggested expatriates' role as headquarters representative, power and control, and work centrality, which we interpreted as manifestations of identification with the manager role. We defined/coded as foreigner identity the instances where expatriates self-defined as being not a local; they often defined themselves as a distinctive type of privileged foreigner (with high professional and financial status) living in expensive residential areas (expatriate communities) 
inhabited mainly by corporate expatriates. We defined/coded as national identity the instances to which the data suggested national identification and pride with one of the Nordic countries. Expatriates with salient national identity sought to differentiate themselves from locals, having an outsider mentality in both countries. We defined/coded as host country identity the instances where the expatriates made statements that suggested identification with the host country culture. We also found the attitudes by locals in both countries regarding their social segregation towards expatriates were related to expatriates' host country identity.

Some of our data mapped on the second-order categories (manager identity or foreigner identity), i.e., where the expatriates claimed these identities, giving us further confidence that the more indirect codes (i.e., behaviors and attitudes that relate to these identities) are expressions of these identities. In a later stage, we combined the manager and the foreigner identity under one overarching category labeled as the expatriate identity, since these two initial identity categories had significant overlaps in the data. We also discovered that the national and the host country identity can be grouped into an overarching category of cultural identity. These identities were not necessarily experienced independently, but often in a way that suggested they are better understood when considered as facets of the overall cultural identity. The coding structure detailed above is shown in Table 2, along with interview examples, and the percentage of expatriates mentioning topics for each of the categories identified.

Insert Table 2 about here

Our data suggest that the identity categories demonstrated considerable variation in terms of stability and change. In particular, manager identity was more stable than host country identity. 
Identity theory suggests that people reinforce their salient identities through identity verification (Burke \& Stets, 2009). Following this rationale, we identified/coded work and non-work-related identity verification processes. In line with the identity theory, our data show that the expatriates reinforced their salient identities with like-minded expatriates in both countries. As a sign of identity validation, the expatriates often compared themselves with each other and emphasized that other expatriates have similar experiences. Identity theory also holds that identity change can occur through identity disruptions (Burke, 1991). Following this rationale, we identified/coded work and non-work-related identity changes. Our data suggest that frequent interactions with locals increased identity disruptions, which in turn were related to expatriate adjustment. Our coding concepts and examples are shown in Table 3.

Insert Table 3 about here

Next, we proceeded to capture expatriate adjustment. We started by coding our data into general, interaction, and work adjustment (Black \& Stephens, 1989). Instead of these facets, we identified two work and non-work-related categories of adjustment, both respectively revealing the degree of adjustment to interaction with the locals at work and non-work settings. Instead of reactively adjusting to the environment, our data also suggest that expatriates proactively sought to influence their environment. Guided by the theory of work role transitions (Nicholson, 1984), we identified/coded two modes of work- and non-work adjustment: proactive mode and developmental/passive mode. These modes of adjustment respectively reveal how expatriates seek to change their work and non-work context to correspond to their needs or adjust to their work and non-work context. Our coding concepts and examples are shown in Table 4. 
Insert Table 4 about here

\section{Findings}

Our analysis suggests that the expatriate identity (i.e., identifying with being a manager and a foreigner) and the cultural identity (i.e., identifying with the national culture and the host country culture) matter in understanding the mode and degree of expatriate work- and non-work adjustment.

\subsection{Expatriate Identity}

\subsubsection{Manager Identity}

Expatriates with high legitimate power and professional status at work often identified strongly with their (foreign) manager identity. This identity was more salient to expatriates in higher organizational ranks. Sent from corporate headquarters with specific performance targets, the expatriates reasoned that their role as foreign managers was to increase the profitability of operations in host countries. As reasoned by an expatriate [J21] in Japan: "I am a specialist in this field. I am also Asia Pacific Business Manager. I need to add value in the business somehow. It is the reason why I am sitting here". In China, an expatriate [C18] explained: "People [local employees] here see me as representing the mother company [in Finland], which automatically gives me a position of power. I am the one who basically pays their salaries. That also gives me natural power." This manager identity was particularly salient with expatriates sent to foreign subsidiaries with the purpose of taking over local top managers and to revitalize host country operations. Guided largely by their own preferences and the rationale of global best practices rather than directives from corporate headquarters, the expatriates questioned the appropriateness 
of local ways of managing operations and conducting business. But even if their appointment was not specifically defined, they often reasoned that their role as an expatriate manager was to initiate changes. In Japan, an expatriate [J34] explained: "Here were many things which were not according to my management...there were casualties [local employees fired]. There are quite a few new people in this organization." In several cases, local employees resisting, or unable to adjust to new practices were fired.

The identity of expatriates as managers was associated with authority, power, and professionalism; expatriates who provided accounts suggesting salient identification with their role were the ones who sought to shape their environment to their preferences than to adjust to it. Expatriates in top management positions were particularly determined and confident in pursuing such changes. In Japan, an expatriate [J29] reasoned: "If you are too soft [to demands by local employees], you will end up giving in and then your authority is gone." This interpretation of the manager role as having to impose certain approaches is at odds with work adjustment defined often as a degree of familiarity with work practices in host countries (Black \& Stephens, 1989). Instead of adjusting to practices in host countries, the expatriates having salient foreign manager identity preferred and adopted the opposite approach: adjusting the work environment to their preferences. In China, expatriates perceived their manager roles similarly; as noted by one of them [C8]: "Top management in Beijing is Danish and Finnish people, so we [expatriates] are keeping the Western culture in the management team." This identity was verified and reinforced in interactions with headquarters and like-minded expatriates in both countries. These identity verification processes can explain the relative stability of foreign manager identity over time. In general, these expatriates seemed to operate with a mindset associated with the manager identity 
where their value is derived from growing local operations; such a goal was also perceived to be in contrast to adjusting to local practices.

Being often at odds with local practices, expatriates' manager identity was challenged in foreign subsidiaries. In China, they were judged by their local subordinates as to whether they can bring anything good to the subsidiary without (presumably) knowing the local language and culture. In particular, senior local managers often questioned expatriates' initiatives, authority, and capability to lead employees in both countries. In China, an expatriate [C4] explained: "I faced a lot of problems with [local] colleagues, especially those who were thinking that they would do those things that I came here to do. I was asked many times 'why are you here?'”. In Japan, expatriates were often confronted by local senior managers. For instance, an expatriate [J29] was asked: "Why do we need a foreigner? Why do we need you?" While expatriates with a salient manager identity sought to solve identity disruptions by shaping their environment based on their own preferences through persuasion or firing local employees who challenged them, power battles with local senior managers were a common occurrence. In Japan, an expatriate [J22] said: "He [the local manager] had a lot of animosity towards me because I took the job. For half a year, I started to work from 6 o'clock in the morning. He tried to cope [by trying to work as hard as I did] but eventually had to give up. And everybody knew that I worked harder. So, I selected a few battles and he lost them".

Because of the resistance they encountered, expatriates having a salient manager identity considered it important to monitor and micromanage local employees to ensure that their directives were implemented. In Japan, an expatriate [J34] explained: "Monitoring is taking 80\% of my time. That is very important. Otherwise, they [local employees] will mislead me in many ways". In China, local employees were seen to deliberately slow down change processes due to 
their passiveness. As explained by an expatriate [C2]: "They expect you to support them, to make the decision, even the smallest ones. If you guide them wrongly, they [still] do what you have told them to do, but they don't necessarily think whether it's the right way or wrong way." With the understanding of what a manager does in Nordic countries, the expatriates were often frustrated with the constant need to micromanage local employees. Local employees related to them as managers, but not in a way they would expect them to. In both countries, expatriates verified their identities and sought to improve their adjustment by changing their environment and by distinguishing themselves from locals. For instance, the manager identity and adjustment in China were linked to feelings of superiority in relation to locals. While some expatriates in Japan felt superiority to locals especially in terms of flexibility and creativity, many of them admired the local employees' strong work ethic. As explained by an expatriate [J19]: "In Europe, people go home at 4 o'clock. Job is not the main driver of their lives. Here it is. In the Japanese eyes, we are not working hard. Japan is one of the toughest countries. It is very difficult to compete with them".

At times, the identity of expatriates as foreign managers was shaped/reformed through identity disruptions. Occurring when a salient role identity is in jeopardy, the disruptions made expatriates reflect on their manager identity and related behaviors. Instead of seeking to change their environment, these expatriates had more favorable perceptions of and towards using more locally congruent practices. In Japan, an expatriate [J38] reasoned: "foreigners often go wrong because they don't understand how this country works. In comparison to many other European managers here, I adopt many things to local ways." In China, an expatriate [C2] admitted that at the beginning of his assignment, he would lose his temper and shout at his local subordinates due to incongruent expectations/preferences. Over time, he learned to manage his subordinates more 
effectively: "I can be demanding, and people respect me even though I don't necessarily yell. It has been interesting journey to try to keep the temper and not to lose the control, regardless of all the hassles that are sometimes taking place." Such inconsistencies in expectations/preferences on the one side and expatriates' experiences in interactions with local employees on the other were often the trigger for role redefinition. These instances prompted the expatriates to reflect on their assumed identity as managers; depending on how the reflection was managed, it could initiate changes in their manager identities, and influence work adjustment.

The identity of expatriates as managers appeared not to affect their non-work adjustment. The expatriates with salient manager identity focused on developing local operations, having little time or interest in interacting with locals beyond work-related matters or to engage with non-work activities. They sought to initiate changes to local practices, to "leave their own positive mark" [J23] that reinforces their manager identity and provides them with more career-related opportunities. In fact, this was often the very reason why they had accepted the international assignment and had agreed to work in countries that, in their eyes, were “challenging". In Japan, an expatriate [J33] reasoned: "If the job is interesting, I choose it. Everyone wants to go to Sydney in my company. I think that Australia is boring in terms of business. You can go there when you are 60 [years old] and have nothing more to achieve". In China, two expatriates stated: "My being here is work-driven" [C18] and "as an expatriate I work a lot. In the evening, I return home and spend time with my family. I don't need to adapt much" [C3]. Our findings thus suggest that, instead of adapting to local conditions, the expatriates sought to maintain their home country lifestyle in both countries.

\subsubsection{Foreigner Identity}


All expatriates are by definition "foreigners" while on their international assignments. This increased the salience of foreigner identity in China and Japan. Due to their distinctiveness from locals and their financial and professional status, the expatriates often had a strong feeling of being "privileged foreigners in a foreign land" [C21]. Initially, most of them welcomed and were excited about this distinctiveness of being "white foreigners" [e.g., C11 and J25] in China and Japan. Strengthening identity verification, expatriates were regarded by locals as a specific class of foreigners with high financial and professional status. For this reason, they identified themselves and wanted to be identified by locals as different from "other foreigners" in China and Japan (i.e., foreigners who work in local organizations, rather than expatriates sent by an MNC). In Japan, other foreigners from Western countries often work as language teachers on modest salaries and with low opportunities for career advancement and mobility. The expatriates often highlighted these differences in relation to other co-nationals with a different role/status; they emphasized that being an expatriate was not something that every colleague in their home country could achieve. In China, an expatriate [C5] noted: "In China, some things are very easy because of my expatriate status. For example, in Finland we could not afford to hire a cleaning lady even though we both were working." The various benefits that come with this role, such as high salaries and good relocation packages, encourage expatriates to assume and maintain another identification: being a privileged foreigner.

The differences in terms of financial status and lifestyle between locals and expatriates enhanced the salience of the foreigner identity. For instance, one expatriate [C3] compared his lifestyle in France and China: "In France, the difference between being a Frenchman, living as a local French[man], and being an expat on an assignment, is not that big. In China, there is a huge difference between those things. It's a complete and separate bubble to work as an expatriate 
here. You have your kids in schools with other foreign kids...you cannot claim that you live in China. Geographically yes, but it isn't the same as living in France [as an expatriate]. Your social circles here are other foreigners mainly." In China, another expatriate [C20] said: "This Upper East area [where I am currently living] is a luxury area. It's really expensive here, those who live here, their income is much higher than Chinese people." In China, expatriate communities are tight-knit, and expatriates have limited interactions with locals. In Japan, the expatriates lived in expensive areas but in ones mostly populated by locals and were a small, distinctive minority among locals. These expatriates still wanted to emphasize their privileged foreigner status: one way to do that was for them to mention the area of their residence often (without being prompted to talk about this during interviews) and by making repeated references to interactions with other corporate expatriates. Despite some spillover effects on work adjustment, foreigner identity had a stronger relation to non-work adjustment due to family (e.g., children's education), lifestyle, and housing-related factors.

The foreigner identity appeared not to hinder non-work adjustment largely because these expatriates lived in separate communities with limited social interactions with locals. In China, most expatriates reasoned that living in an exclusive, upper-class neighborhood was easy, and they had the financial means to support their lifestyle. As noted by one expatriate [C3]: "It is especially fun to be an expatriate in China. You can have a driver and go to fancy places." The expatriate life included outings to places popular with other corporate expatriates and a limited number of locals able to interact with expatriates through foreign language proficiency and who were interested in doing so. Another expatriate [C13] said: "I have a lot of benefits which are only for [corporate] expats, house and cars, school fees for children.” In Japan, expatriates [e.g., $\mathrm{J} 2$ and J25] acknowledged benefits such as housing and international schools for their children 
which made their adjustment easier. In addition to their ethnic distinctiveness from locals, these factors could explain why foreigner identity was relatively salient over time in China and Japan. In both countries, the temporality of the assignment also influenced social interactions with locals and host country embeddedness. An expatriate in China [C23] explained: "Even though I have a continuous contract, I always only think of one year at a time. Basically, all this time, I am prepared that [at] any time I may need to return home. All the time I am thinking that I am a Finnish citizen living in China. I never feel, and I never intend to stay here for the rest of my life." While an expatriate in Japan [J6] noted: "I have a contract here for three years. It can be shorter or longer. Because I stay here only for few years, there is no reason to develop friendships with locals".

\subsection{Cultural Identity}

\subsubsection{National Identity}

National identity was linked to a desire to maintain a connection with the home country (beyond the headquarters) but was also triggered and reinforced by comments and attitudes from the locals in both countries. The expatriates with salient national identity identified themselves and wanted to be identified by locals as expatriates from Nordic countries, instead of being regarded as a generic expatriate or misplaced in terms of origin. In Japan, several expatriates lamented that they were disappointed to be seen by locals as "US Americans" [e.g., J16 and J28], and that the locals were not aware of or interested in their Nordic origins. In China, expatriates from Nordic countries were less visible and acknowledged by locals than their counterparts from larger Western countries, especially from the USA. In part to maintain and reaffirm their Nordic identity, expatriates have developed and reinforced specific subgroups in the larger expatriate communities in China and Japan. These subgroups were supported and legitimized not only by 
the informal connections between organizations and expatriates from the Nordic countries but also by the Chambers of Commerce and expatriate societies. As a result, expatriates developed a strong national identity, as reflected in their comments: "I never want to identify myself with anything else than Finland" [C21], and "I have been here for eight years, but I will never be Japanese" [J45]. While such identification helped expatriates to maintain and reaffirm their cultural reference point, it also affected how well and in what way they adapted to the host country.

In general, having a strong national identity tended to make expatriates want to change the local environment, i.e. replacing the local practices with practices from "home". Perceiving the environment through national identity filters made these expatriates often unable or unwilling to understand or appreciate different values and practices. In China, one expatriate [C8] reasoned that their business practices "are in the Finnish way because it is a Finnish company...it is better to keep the Western culture in the management". In Japan, an expatriate [J46] explained: “This [foreign] subsidiary is exactly like any other [MNC X foreign] subsidiary around the world. It just happens to be full of Japanese people”. Referring to their national identity, expatriates provided accounts where they regarded local practices as inherently bad or improper, especially when these conflicted with their home country practices. One expatriate in Japan [J31] stated: "Japanese thinking is system bound. As long as they follow the system, everybody does the same stupid things, everybody is happy, and no one can be blamed. But if you do something different and you don't succeed, you lose your position, guaranteed...creativity is very low. Scandinavian countries are totally different". These expatriates contrasted home and host countries, valuing home country practices and devaluing host country practices. In these cases, a strong national identity hindered how well expatriates felt adjusted in the host country. Locals were often not 
welcoming of such criticisms, something which increased animosity between expatriates and locals, limiting expatriates' social networks and interactions to like-minded expatriates. These identity verification processes with like-minded expatriates appeared to increase the salience of national identities and negative perceptions of host countries.

However, our analysis also suggests that national identity is not necessarily associated with low host country adjustment. In some cases, expatriates actively promoted their national identities and practices in a positive way that facilitated bridging between cultures, and connection with locals. In Japan, a Finnish top manager dressed as Santa Claus [a Finnish cultural icon] and gave presents at his company's Christmas party. This expatriate [J4] reasoned: "They have not seen Santa before... by doing this I try to bring myself to the employee level". As well as dressing up as Santa for entertainment purposes, the expatriate was also seeking to develop closer relations with local employees accustomed to rigid hierarchies in Japan. In this way, expatriates sought to shape their environment in a less imposing manner, and this facilitated their adjustment, even if the actions were guided by the expatriates' national identity. Expatriates also used positive images related to their countries, such as gender equality, design, and nature, to promote themselves, and their MNCs and products in both countries. In China, one expatriate [C21] framed such instances in the following way: "I see Finland as a small, a very good country. I do a lot of free marketing for Finland. In that sense, I am a sort of ambassador for Finland". The relationship between national, cultural identity and adjustment is therefore complex and nuanced. Expatriates with a more reflective stance towards their national identity and who promoted their national identities in positive ways rather than imposing their views on locals, tended to be well adjusted.

\subsubsection{Host Country Identity}


Instead of having salient national identity, some expatriates had internalized local cultural elements and did not feel like a typical Nordic anymore. For instance, some expatriates reasoned: "my values and ways of doing things are leaning towards the Chinese side nowadays [C14]" and "I have lived so long in Japan that I am used to the system. In fact, I often feel like Japanese" [J1]. These identity changes were often attributed to close relationships with locals, such as marriages or stable partnerships. With their partners being a local Chinese/Japanese person, these expatriates had more in-depth and more frequent social interaction not only with their partners, but also with the networks of their partners such as families, friends and other business contacts. The additional interactions with locals have often given these expatriates confidence and a positive feeling about working in the host country. In general, expatriates with salient host country identity favored host country practices and experienced high work adjustment. However, our data also suggest considerable differences in expatriate identities. Although some of them showed salient Nordic national identities; others had conflicting identities, and others showed stronger identification with the host country culture. For instance, an ethnic Chinese expatriate (born in China, but moved to Finland during childhood) [C16] explained: "Being a Finn is easy. When you try to be Chinese, it is more difficult. It is very tiring. I have to think twice what I say and what I can do." However, a Danish-Japanese expatriate [J39] in Japan reasoned: "Besides some problems with technical kanji [logographic characters], I feel like a Japanese [person].” Instead of the mere length of host country experience, tight networks with locals and early childhood exposure to a host country can explain why expatriates accepted and internalized host country cultural values and practices.

The expatriates with salient host country identity were the ones who sought to immerse themselves in the host country culture and to develop social contacts on their own and through 
their local colleagues, friends, and/or spouses. They sought to interact more with the locals than with other foreigners and immersed themselves in various cultural aspects of China and Japan. These interactions tended to increase expatriates' cultural awareness and appreciation, and host country identity salience. The salient host culture identity and interactions with locals (initially) gave these expatriates the feeling that they were also accepted by locals, despite the fact that a social categorization of people into in- and outgroups is common in collective cultures such as China and Japan (Brewer \& Yuki, 2007; Triandis, 1989). Expatriates with a salient host culture identity often felt accepted and psychologically comfortable working and living in the host country. However, when experiencing social segregation and negative comments from locals, they tended to experience identity disruptions. Feeling rejected by locals, despite their efforts to integrate into local cultures, caused expatriates stress and frustration, and had a negative relation to their adjustment. In China and Japan, disappointed expatriates lamented: "I am really tired of the whole thing that you don't understand because you are a foreigner" [C24], and "No matter what I do and how much I try, I am still treated as an outsider" [J11]. As a result of frequently encountered social segregation between locals and foreigners in China and Japan and the emotional frustrations they suffered, expatriates with salient host country identities often felt alienated and maladjusted, and thus expressed the wish to leave the host country (as in the case of C24 and J11).

\section{Discussion}

This study revealed multifaceted identities experienced by corporate expatriates and how these identities are related to their host country adjustment. More specifically, we used the symbolic interactionism-based identity theory (Burke, 1991; Stryker, 1980) and qualitative data from China and Japan to distinguish two interrelated identities - the expatriate identity and the 
cultural identity - that matter in understanding the mode and degree of expatriate work- and non-work adjustment. For instance, those experiencing a strong expatriate identity tended to make changes to their local working environment instead of adapting to it. Our analysis leads us to develop an abductively-derived model (see Figure 1), suggesting that the relation between these identities and adjustment occurs through identity stability and change. Although identity verification processes reinforce existing salient identities, identity disruptions lead to identity change. For instance, our analysis shows that expatriates reinforced manager-, foreigner-, and national identities in interactions with like-minded expatriates, which were in turn related to their adjustment.

Insert Figure 1 about here

\subsection{Theoretical Contributions}

This study contributes to research on expatriates by using the identity theory (Burke, 1991; Stryker, 1980) and qualitative data to explore multifaceted identities that guide expatriates' attitudes and behaviors, and through identity stability and change, the degree and mode of work, and non-work adjustment. Identity theory is beneficial in expanding an understanding of expatriate identities and adjustment because it explains how roles and life experiences associated with significant transitions alter individuals' sense of self and their subsequent attitudes and behaviors toward their work and non-work surroundings. Through the concepts of identity verification and disruption, it also provides the theoretical rationale for identity stability and change. Despite its relevance and applicability, to date only two studies have used the identity theory in expatriate settings: Shaffer and Harrison (2001) applied it in conjunction with social 
identity theory to examine the adjustment of expatriates' spouses, and Kraimer et al. (2012) used it to study how international employee identity is related to repatriates' turnover. Adding to this research by focusing on the identities as experienced by expatriates during their international assignments, we used the identity theory to explore the experience of being an expatriate as a relevant identity anchor in its own right. We demonstrated how identity theory can be used to address questions related to expatriate identity stability and change, and adjustment in host countries, which remains an important and theoretically interesting area in expatriate research. By undertaking an in-depth exploration of expatriates' experiences in two host countries, we captured expatriates' distinct work- and non-work identities, and more importantly, drew attention to an identity that is central to employees in their international assignments, and one which has been largely overlooked: that of being an expatriate.

Providing a holistic account of multifaceted identities as experienced by expatriates, our study also answered calls for novel perspectives on the identities of expatriates (Adams \& van de Vijver, 2015). We went a step beyond previous studies that have focused on expatriates' cultural identity (Kohonen, 2004; Näsholm, 2012; Scurry et al., 2013), highlighting the importance of a work-related identity dimension: the expatriate identity (i.e., an amalgam of identifying with the manager role but also with the foreigner dimension of being an expatriate). Our findings suggest that belonging to multiple identity groups is inevitable and relevant to the selfhood of expatriates during their international assignments. Furthermore, our findings reveal a complex interrelation between expatriate identity and cultural identity dimensions - how expatriates feel as a manager working on a foreign land at work cannot be separated from how they relate to their home and host country culture outside work (as distinguished in Figure 1 in terms of background color). Expanding existing knowledge on expatriates' cultural identities (Kohonen, 2004; Näsholm, 
2012; Scurry et al., 2013), our findings, in line with prior works on cultural identity, also provide evidence that people who identify with the culture of the host country develop more culturally diverse social networks (Mao \& Shen, 2015).

By empirically linking the foreign manager and cultural identities of expatriates with work- and non-work adjustment, this study went beyond prior conceptual and empirical works on expatriate cultural identities (Kohonen, 2008; Mao \& Shen, 2015; Näsholm, 2008; Scurry et al., 2013) and undifferentiated approaches to conceptualizing adjustment (Mao \& Shen, 2015). To our knowledge, this is the first empirical study focused on linking the identities of expatriates and adjustment detailed in its two forms, work- and non-work-related. Our analysis suggests that the expatriates with salient manager identity, in particular, focused on work and had little time for, or interest in, non-work-related interactions with locals. Our findings provide some evidence that expatriate specific work roles could matter as well, because manager identity appeared to be the most salient among expatriates who were sent from corporate headquarters to make foreign subsidiaries more efficient in terms of financial performance. Further, expatriates with salient foreigner identity often lived in expatriate enclaves and limited their social interactions to other expatriates and a limited number of international-minded locals. Our analysis also suggests that, in contrast to the expatriate identity, expatriates with salient cultural identity were more adjusted to non-work-related aspects in both host countries.

The identity theory perspective used also contributes to research on expatriate identities by suggesting that identity verification and identity disruption processes respectively can explain expatriates' identity stability and change during international assignments. While scholars have provided retrospective accounts of identity change and stability during international assignments (e.g., Kohonen, 2008; Näsholm, 2011; Scurry et al., 2013), they have not provided a theoretical 
rationale as to why these identity shifts occur and how they are related to expatriate adjustment. A notable exception is the study by Kraimer et al. (2012) on international employee identity and repatriate turnover. According to Kraimer et al., identity strain (i.e., an individual's feelings of tension associated with his or her international employee identity being inconsistent with the current environment) has a positive impact on repatriate turnover. In contrast to Kraimer et al.'s study of repatriates' international employee identity, we provided a broad account of expatriate identities during their international assignments and explored reasons for identity stability (i.e., identity verification) and identity change (i.e., identity disruption) and a way of linking expatriate identities to host country adjustment. Our findings also suggest considerable variation of stability and change in expatriate identity dimensions and that identity stability does not need to have a negative relation to work and non-work adjustment. In particular, the manager and foreigner aspects of expatriate identity were relatively stable over time, and this stability did not hinder adjustment.

Further, this is one of the few studies that suggest it is not necessarily unambiguously good for expatriates to adjust to the local environment. Indeed, whether they are willing to adapt to the local practices or not also depends on expatriates' identities, including cultural identity. Based on Grinstein and Wathieu (2012), expatriates with a less salient cosmopolitan identity would be less inclined to adapt to the host country. They further pointed out that a cosmopolitan expatriate expects a longer duration of expatriation, and a less-cosmopolitan expatriate expects a shorter expatriation duration. In contrast to their quantitative study on cosmopolitan identity and with $70 \%$ of the respondents being self-initiated expatriates, our qualitative study with corporate expatriates also demonstrate that the multifaceted identities expatriates experience, affect not 
only whether they adapt to the local environment, but also whether they actively seek to change their local working environment.

Our findings also complement, and to some extent challenge, the conceptual work suggesting that general host country adjustment is associated with a change in one's cultural identity (Mao \& Shen, 2015). Our findings suggest that, rather than only reactively adapting to the environment, corporate expatriates proactively seek to change their environment to fit their own preferences. Because of their legitimate power in foreign subsidiaries and often-generous expatriate packages, especially expatriates in high organizational positions were often selective in the degree to which they are willing to adjust to host cultures. In terms of work adjustment, expatriates with salient manager identity often emphasized the need to initiate changes in foreign subsidiaries that were in line with their preferences or home-based practices, rather than being willing to consider or explore local practices. Our findings also suggest that expatriates are rather selective in their cross-cultural engagement in their private life domain by choosing to live in areas populated mainly by expatriates and electing to interact with other expatriates. Although this can be a typical arrangement provided by MNCs, our data revealed that these arrangements support important benefits associated with the expatriate identity (i.e., special status). This can explain why the approach persists, in spite of the learning perspective-based suggestions that it is important to engage with the local context when living and working in another country (Black et al., 1991). Although this proactive change of the environment $(\mathrm{P} \rightarrow \mathrm{E})$ by corporate expatriates can be a relatively common phenomenon, it has received relatively little attention in expatriate research. Instead, scholars taking the reactive approach have extensively discussed maladjusted expatriates who, instead of adjusting, return prematurely to their home countries (e.g., Birdseye \& Hill, 1995; Black et al., 1991; Black \& Stephens, 1989). 
Finally, while given little attention in research on expatriate identities, this study answers calls for context in international business research (Gligor, Esmark, \& Golgeci, 2016; Teagarden, Von Glinow, \& Mellahi, 2018) by highlighting the importance of context in expatriate identities and adjustment. Our findings suggest that host country identification and non-work adjustment depend on how accepting and supporting local people are towards expatriates. For instance, the treatment of expatriates as a special type of foreigners by local people in China and Japan made expatriates' foreign identity more salient and were related to their adjustment. Interestingly, our findings provide evidence that even the expatriates of Chinese and Japanese ethnicity who were proficient in local languages had problems in being accepted by locals as ingroup members in both countries. There are also notable differences between the two host countries. For instance, our findings suggest that expatriate manager identity was less salient in Japan due to economic development and technical advancement. In China, the manager identity appeared to be more linked to feelings of economic, technical, social value (e.g., gender equality, work-life balance, and environmental conservation) advancement in relation to locals. In Japan, foreigner identity was less salient among expatriates since they often lived in same residential areas with locals. In China, expatriate communities are tight knit, which reduces interactions with locals. In summary, our findings suggest some context-specific similarities and differences in expatriate identities in China and Japan.

\subsection{Practical Implications}

The findings suggest that expatriates with salient expatriate (manager) identity can be efficient at least in the short term, or for particular objectives because of their prioritization of work-related matters. Individuals that prioritize their expatriate identity can also be the ideal candidates for assignments where the focus is on implementing a global (vs. multidomestic or 
transnational) strategy (Bartlett \& Ghoshal, 1991). In the case of emphasis being placed on the localization strategies, expatriates with a tendency to develop a strong host country identity (as seen in other assignments) might be more efficient, given their likely sensitivity towards and positive views on local values and practices. Thus, MNCs are recommended to investigate and take into consideration the multifaceted identities that expatriates have developed when making reappointments with specific objectives related to particular global strategies. Indeed, neither the employer nor the employee could predict what kind of identities would be developed during an assignment. However, our findings suggested the influences of different identities on expatriate adjustment. We would thus recommend that MNCs take a long-term perspective in training and developing expatriates by offering expatriates in assignment an opportunity to reflect on their identity change.

The findings also suggest that expatriates with host country ethnicity might not be the most effective expatriates since they can experience ambivalent and conflicting host country identities and adjustment problems. While competent in host country culture and language, several such expatriates in our study were not willing to adjust to host countries or to interact with locals because of the ongoing/unresolved identity conflicts. While people with host country ethnicity might appear to be ideal candidates for expatriate assignments, due to their ethnicity and strong cultural and language competencies, we recommend a cautious approach in the selection processes (Selmer \& Shiu, 1999; Fan, Cregan, Harzing, \& Köhler, 2018; Zhang, Harzing \& Fan, 2018).

Finally, because the findings suggest that social interactions can explain the stability and change of expatriate identities, more balanced interactions with other expatriates and locals can facilitate host country adjustment. For instance, frequent and in-depth interactions with local 
employees might help expatriates and locals to treat the opposite group as fellow colleagues working for the same company, instead of different nationalities with imbalanced social status both within the company and in the host country. Within local subsidiaries, such interactions can be facilitated by joint training sessions and periodic social events aiming at promoting both the home and host country cultures. Often such activities are understood as serving the purpose of team building only. Well-designed social events that take the possible identity disruptions into consideration, can help expatriates develop a strong national and/or host country identity in a healthy way.

\subsection{Limitations and Suggestions for Future Research}

Even though we conducted this study in two countries, our findings to a certain extent can be context specific. For instance, locals in China and Japan tend to associate 'foreignness' and 'localness' with physical appearance (often race) and the practice of not accepting foreigners can even be considered to be patriotic in China (Barme, 1995). However, our study suggests that identity dynamics are important in understanding adjustment, with the influence of the expatriate identity being likely to manifest itself in other locations as well. Exploring the role of expatriate identity in other countries is important so as to provide additional insights on these dynamics, further expanding the understanding of expatriate adjustment.

Because the expatriates were interviewed only once, we are not able to provide a genuine process perspective of expatriate identity change and adjustment. Since individuals are not likely to find their identity to change in few weeks or months (Stets \& Burke, 2014), we recommend longer time periods between interviews. Our findings also suggest that temporality influenced expatriates' interactions with locals and local embeddedness. Thus, future research focused on 
the time-related effects on identity and adjustment could be another fruitful way to build on and refine our findings.

Finally, we interviewed mainly corporate expatriates in high organization ranks. Our interviews suggest that expatriates higher in organizational hierarchy tended to have more salient manager identity and, due to their legitimate power, are able to adjust the work environment to their preferences. Our interviews suggest that expatriates in lower organization ranks are less able to do so; however, we are unable to make a clear distinction as we mainly interviewed expatriates in high organization ranks. Thus, future research is recommended to conduct interviews with expatriates in a wider variety of organizational ranks.

\section{Conclusion}

This study contributes to expatriate research in various ways. Perhaps most importantly, it goes beyond the dominant stressor-strain perspectives of expatriate adjustments by using the identity theory to reveal multifaceted identities experienced by corporate expatriates and how these identities are related to their host country adjustment. By doing so, it opens the door for future research on expatriate identities and their relation to work- and non-work-related adjustment.

\section{References}


Adams, B. G., \& van de Vijver, F. J. R. (2015). The many faces of expatriate identity. International Journal of Intercultural Relations, 49, 322-331.

Armstrong, S. J., \& Li, Y. (2017). A study of Anglo expatriate managers' learning, knowledge acquisition, and adjustment in multinational companies in China. Academy of Management Learning \& Education, 16(1), 1-22.

Bader, K., Froese, F.J., \& Kraeh, A. (2018). Clash of cultures? German expatriates' work-life boundary adjustment in South Korea. European Management Review, 15, 357-374.

Barme, G. R. (1995). To Screw Foreigners is Patriotic: China's Avant-Garde Nationalist. The China Journal, 34, 209-234.

Bartlett, C. E., \& Ghoshal, S. (1991). Managing Across Borders: The Transnational Solution. Harvard Business School Press.

Bell, M. P., \& Harrison, D. A. (1996). Using intra-national diversity for international assignments: A model of bicultural competence and expatriate adjustment. Human Resource Management Review, 6(1), 47-74.

Birdseye, M. G., \& Hill, J. S. (1995). Individual, organizational/work and environment influences on expatriate turnover tendencies: An empirical study. Journal of International Business Studies, 26(4), 787-813.

Birkinshaw, J., Brannen, M. Y., \& Tung, R. L. (2011). From a distance and generalizable to up close and grounded: Reclaiming a place for qualitative methods in international business research. Journal of International Business Studies, 42, 573-581.

Black, J. S., \& Gregersen, H. B. (1991). Antecedents to cross-cultural adjustment for expatriates in Pacific Rim Assignments. Human Relations, 44(5), 497-515.

Black, J. S., Mendenhall, M., \& Oddou, G. (1991). Toward a comprehensive model of international adjustment: An integration of multiple theoretical perspectives. Academy of Management Review, 16(2), 291-317.

Black, J. S., \& Stephens, G. S. (1989). The influence of the spouse on American expatriate adjustment in overseas assignments. Journal of Management, 15, 529-544.

Brewer, M. B., \& Yuki, M. (2007). Culture and social identity. In S. Kitayama \& D. Cohen (Eds.) Handbook of Social Identity (pp. 307-322). Guilford Press, New York.

Burke, P. J. (1980). The self: Measurement implications from a symbolic interactionist perspective. Social Psychology Quarterly, 43, 18-29.

Burke, P. J. (1991). Identity processes and social stress. American Sociological Review, 56(6), 836-849.

Burke, P. J., \& Stets, J. E. (2009). Identity theory. Oxford University Press: Oxford.

Edmondson, A. C., \& McManus, S. E. (2007). Methodological fit in management field research. Academy of Management Review, 32, 1155-1179.

Edström, A., \& Galbraith, J. R. (1977). Transfer of managers as a coordination and control strategy in multinational organizations. Administrative Science Quarterly, 22, 248-263.

Fan, S. X. Cregan, C. Harzing, A. W. \& Köhler, T. (2018). The benefits of being understood: The role of ethnic identity confirmation in knowledge acquisition by expatriates. Human Resource Management, 57(1), 327-339.

Fielding, N. 1993. Qualitative interviewing. In N. Gilbert (Ed.), Researching social life (pp. 135153). London: Sage.

Gligor, D. M., Esmark, C. L., \& Golgeci, I. (2016). Building international business theory: A grounded theory approach. Journal of International Business Studies, 47(1), 93-111. 
Grinstein, A., \& Wathieu, L. (2012). Happily (mal)adjusted: Cosmopolitan identity and expatriate adjustment. International Journal of Research in Marketing, 29, 337-345.

Guo, Y., Rammal, H. G., Benson, J., Zhu, Y., Dowling, P. J. (2018). Interpersonal relations in China: Expatriates' perspective on the development and use of guanxi. International Business Review, 27(2), 455-464.

Harzing, A. W. (2001). Of bears, bumble-bees, and spiders: The role of expatriates in controlling foreign subsidiaries. Journal of World Business, 36, 366-379.

Haslberger, A., Brewster, C., \& Hippler, T. (2013). The dimensions of expatriate adjustment. Human Resource Management, 52(3), 333-351.

Hofstede, G. (2001). Culture's consequences: Comparing values, behaviors, institutions and organizations across nations ( $2^{\text {nd }}$ ed.). Sage: Thousand Oaks.

Kohonen, E. (2008). The impact of international assignments on expatriates' identity and career aspirations: Reflections upon re-entry. Scandinavian Journal of Management, 24, 320-329.

Kraimer, M. L., Bolino, M. C., \& Mead, B. (2016). Themes in expatriate and repatriate research over four decades: What do we know and what do we still need to learn? Annual Review of Organizational Psychology and Organizational Behavior, 3, 83-109.

Kraimer, M. L., Shaffer, M., Harrison, D. A., \& Ren, H. (2012). No place like home? An identity strain perspective on repatriate turnover. Academy of Management Journal, 55(2), 399-420.

Kvale, S., \& Brinkman, S. (2015). Interviews: Learning the craft of qualitative research interviewing ( $2^{\text {nd }}$ ed.). Thousand Oaks, CA: Sage.

Lazarova, M., Westman, M., \& Shaffer, M. A. (2010). Elucidating the positive side of the workfamily interface on international assignments: A model of expatriate work and family performance. Academy of Management Review, 35(1), 93-117.

Maertz, C. P., Hassan, A., \& Magnusson, P. (2009). When learning is not enough: A process model of expatriate adjustment as cultural cognitive dissonance reduction. Organizational Behavior and Human Decision Processes, 108(1), 66-78.

Maertz, C. P., Takeuchi, R., \& Chen, J. (2016). An episodic framework of outgroup interaction processing: Integration and redirection for the expatriate adjustment research. Psychological Bulletin, 142(6), 623-623.

Mao, J., \& Shen, Y. (2015). Cultural identity change in expatriates: A social network perspective. Human Relations, 68(10), 1533-1556.

Mead, G. H. (1934). Mind, Self, and Society: From the Standpoint of a Social Behaviorist. Chicago: University of Chicago Press.

Molinsky, A. (2007). Cross-cultural code-switching: The psychological challenges of adapting behavior in foreign cultural interactions. Academy of Management Review, 32(2), 622-640.

Morgan, G., \& Smircich, L. (1980). The case for qualitative research. Academy of Management Review, 5(4), 491-500.

Nicholson, N. (1984). A theory of work role transitions. Administrative Science Quarterly, 29, 172-191.

Näsholm, M. H. (2012). Global careerists' identity construction: A narrative study of repeat expatriates and itinerants. International Journal of Managing Projects in Business, 5(4), 804-812. 
Olsen, J. E., \& Martins, L. L. (2009). The effects of expatriate demographic characteristics on adjustment: A social identity approach. Human Resource Management, 48(2), 311-328.

Peltokorpi, V., \& Froese, F. J. (2012). The impact of expatriate personality traits on cross-cultural adjustment: A study with expatriates in Japan. International Business Review, 21(4), 734-746.

Pierce, C. S. (1903). Pragmatism as a principle and method of right thinking: The 1903 Harvard lectures on pragmatism. Albany: Suny Press.

Reitz, D. C., \& Murtan, E. J. (1994). Multiple roles and identities: factors influencing self-esteem among middle-aged work men and women. Social Psychology Quarterly, 57, 313-325.

Ren, H., Shaffer, M. A., Harrison, D. A., Fu, C., \& Fodchuk, K. M. (2014). Reactive adjustment or proactive embedding? Multistudy, multivawe evidence for dual pathways to expatriate retention. Personnel Psychology, 67(1), 203-239.

Scurry, T., Rodriguez, J. K., \& Bailouni, S. (2013). Narratives of identity of self-initiated expatriates in Qatar. Career Development International, 18, 12-33.

Selmer, J. (1999). Culture shock in China? Adjustment pattern of western expatriate business managers. International Business Review, 8(5-6), 515-534.

Selmer, J. (2004). Expatriates' hesitation and the localization of Western business operations in China. The International Journal of Human Resource Management, 15(6), 1094-1107.

Selmer, J. \& Shiu, S.C. (1999). Coming Home? Adjustment of Hong Kong Chinese Expatriate Business Managers Assigned to the People's Republic of China. International Journal of Intercultural Relations, 23(3), 447-465.

Shaffer, M. A., \& Harrison, D. A. (2001). Forgotten partners of international assignments: Development and test of a model of spouse adjustment. Journal of Applied Psychology, 86(2), 238-254.

Stahl, G. K., \& Caligiuri, P. (2005). The Effectiveness of Expatriate Coping Strategies: The Moderating Role of Cultural Distance, Position Level, and Time on the International Assignment. Journal of Applied Psychology, 90(4), 603-615.

Stets, J. E., \& Burke, P. J. (2014). The development of identity theory. Advances in Group Processes. 31, 57-97.

Styker, S. (1980). Symbolic interactionism: A social structural version. Menlo Park, CA: Benjamin/Cummings Publishing Company.

Styker, S., \& Burke, P. J. (2000). The past, present, and future of an identity theory. Social Psychology Quarterly, 63, 284-297.

Sussman, N. (2000). The dynamic nature of cultural identity throughout cultural transitions: Why home is not so sweet. Personality and Social Psychology Review, 4(4), 355-373.

Takeuchi, R. (2010). A critical review of expatriate adjustment research through a multiple stakeholder view: Progress, emerging trends, and prospects. Journal of Management, 36(4), 1040-1064.

Teagarden, M. B., Von Glinow, M. A., \& Mellahi, K. (2018). Contextualizing international business research: Enhancing rigor and relevance. Journal of World Business, 53(3), 303-306.

Triandis, H. C. (1989). The self and social behavior in different cultural contexts. Psychological Review, 96, 269-289.

Van Maanen, J., Sorensen, J. B., \& Mitchell, T. R. (2007). The interplay between theory and method. Academy of Management Review, 32(4), 1145-1154. 
Vora, D., Kostova, T., \& Roth, K. (2007). Roles of subsidiary managers in multinational corporations: The effect of dual organizational identification. Management International Review, 47, 595-620.

Zhang, L. E., Harzing, A. W., \& Fan, S. X. (2018), Managing expatriates in China: A language and identity perspective. Palgrave Macmillan: London. 


\section{Appendix. Guiding questions in interview protocols}

1. May I have your name and position in this subsidiary? How many people are working in this foreign subsidiary? How many expatriates are working in this foreign subsidiary?

2. What does it mean to be an expatriate in China/Japan?

3. What does it mean to be a foreigner in China/Japan?

4. Can you describe your interactions with foreigners (expatriates) and locals in work and non-work settings?

5. Have you noticed that you think and act/behave differently now than before this expatriate assignment? How?

6. How well you are adjusted to life in China/Japan?

7. Do you feel it's necessary to adjust to China/Japan? Why? 
Table 1. Study participants

\begin{tabular}{|c|c|c|c|c|c|c|c|c|c|c|c|}
\hline Code & $\begin{array}{l}\text { Expatriate } \\
\text { Nationality }\end{array}$ & $\begin{array}{l}\text { Expatriate } \\
\text { Ethnicity }\end{array}$ & Gender & Age & $\begin{array}{l}\text { Years } \\
\text { in host } \\
\text { country }\end{array}$ & $\begin{array}{l}\text { Years in } \\
\text { other foreign } \\
\text { countries }\end{array}$ & $\begin{array}{l}\text { MNC } \\
\text { tenure } \\
\text { (years) }\end{array}$ & Position & Industry & $\begin{array}{l}\text { Place and } \\
\text { year of } \\
\text { interview }\end{array}$ & $\begin{array}{l}\text { Interview } \\
\text { length } \\
\text { (minutes) }\end{array}$ \\
\hline $\mathrm{C} 1$ & Finland & Finland & Male & $41-50$ & 5 & 1 & 13 & Top manager & Telecommunications & Beijing, 2012 & 72 \\
\hline $\mathrm{C} 2$ & Finland & Finland & Male & $31-40$ & 1 & 1 & 14 & Top manager & Telecommunications & Beijing, 2012 & 54 \\
\hline C3 & Finland & Finland & Male & $41-50$ & 4 & 4 & 15 & Manager & Telecommunications & Beijing, 2012 & 85 \\
\hline $\mathrm{C} 4$ & Finland & Finland & Male & $31-40$ & 4 & 0 & 13 & Manager & Telecommunications & Beijing, 2012 & 97 \\
\hline $\mathrm{C} 5$ & Finland & Finland & Male & $31-40$ & 6 & 0 & 14 & Manager & Telecommunications & Beijing, 2012 & 99 \\
\hline C6 & Finland & Finland & Male & $41-50$ & 2 & 6 & 16 & Top manager & Telecommunications & Beijing, 2012 & 57 \\
\hline $\mathrm{C} 7$ & Finland & Finland & Female & $51-65$ & 1 & 1 & 30 & Top manager & Telecommunications & Beijing, 2012 & 48 \\
\hline $\mathrm{C} 8$ & Finland & Finland & Male & $31-40$ & 2 & 1 & 10 & Manager & Telecommunications & Beijing, 2012 & 60 \\
\hline C9 & Finland & Finland & Male & $31-40$ & 2 & 0 & 3 & Manager & Telecommunications & Beijing, 2012 & 63 \\
\hline $\mathrm{C} 10$ & Sweden & Sweden & Male & $31-40$ & 1 & 4 & 4 & Top manager & Consulting & Beijing, 2012 & 103 \\
\hline $\mathrm{C} 11$ & Finland & Finland & Male & $41-50$ & 9 & 1 & 14 & Manager & Wood and Paper & Beijing, 2012 & 75 \\
\hline $\mathrm{C} 12$ & Finland & Finland & Male & $51-65$ & 3 & 1 & 14 & Top manager & Wood and Paper & Beijing, 2012 & 70 \\
\hline $\mathrm{C} 13$ & Finland & Finland & Male & $41-50$ & 1 & 3 & 20 & Top manager & Wood and Paper & Beijing, 2012 & 90 \\
\hline $\mathrm{C} 14$ & Finland & Finland & Male & $51-65$ & 4 & 7 & 21 & Top manager & Metal Processing & Beijing, 2012 & 89 \\
\hline $\mathrm{C} 15$ & Sweden & Sweden & Male & $31-40$ & 1 & 2 & 5 & Manager & Telecommunications & Beijing, 2012 & 56 \\
\hline $\mathrm{C} 16$ & Finland & China & Male & $20-30$ & 1 & 8 & 1 & Manager & Consulting & Beijing, 2012 & 65 \\
\hline $\mathrm{C} 17$ & Finland & Finland & Male & $20-30$ & 3 & 1 & 2 & Manager & Clean Technology & Beijing, 2012 & 85 \\
\hline $\mathrm{C} 18$ & Finland & Finland & Male & $31-40$ & 0 & 1 & 10 & Top manager & Clean Technology & Beijing, 2012 & 84 \\
\hline C19 & Finland & Finland & Male & $51-65$ & 20 & 20 & 37 & Top manager & Travel & Beijing, 2012 & 46 \\
\hline $\mathrm{C} 20$ & Finland & Finland & Male & $31-40$ & 1 & 1 & 10 & Manager & Power/Automation & Beijing, 2012 & 88 \\
\hline $\mathrm{C} 21$ & Finland & Finland & Male & $31-40$ & 3 & 1 & 2 & Manager & Medical Equipment & Beijing, 2012 & 141 \\
\hline $\mathrm{C} 22$ & Finland & Finland & Female & $20-30$ & 4 & 9 & 4 & Manager & Environment & Beijing, 2012 & 55 \\
\hline $\mathrm{C} 23$ & Finland & Finland & Male & $31-40$ & 8 & 1 & 7 & Manager & Glass Processing & Beijing, 2012 & 90 \\
\hline $\mathrm{C} 24$ & Finland & Finland & Male & $41-50$ & 20 & 2 & 5 & Top manager & Glass Processing & Beijing, 2012 & 67 \\
\hline $\mathrm{C} 25$ & Finland & Finland & Female & $20-30$ & 2 & 3 & 1 & Manager & Manufacturing & Beijing, 2012 & 50 \\
\hline $\mathrm{C} 26$ & Finland & Finland & Male & $20-30$ & 2 & 5 & 1 & Manager & Education & Beijing, 2012 & 68 \\
\hline $\mathrm{C} 27$ & Finland & China & Male & $31-40$ & 8 & 7 & 8 & Manager & Consulting & Beijing, 2012 & 87 \\
\hline $\mathrm{J} 1$ & Norway & Norway & Male & $31-40$ & 13 & 1 & 17 & Top manager & Pharmaceutical & Tokyo, 2010 & 30 \\
\hline $\mathrm{J} 2$ & Finland & Finland & Male & $51-65$ & 10 & 0 & 20 & Top manager & Wood and paper & Tokyo, 2010 & 35 \\
\hline $\mathrm{J} 3$ & Sweden & Sweden & Male & $41-50$ & 6 & 0 & 3 & Top manager & Consumer products & Tokyo, 2010 & 110 \\
\hline J4 & Finland & Finland & Male & $41-50$ & 4 & 0 & 1 & Top manager & Electronics & Tokyo, 2010 & 67 \\
\hline J5 & Finland & Finland & Male & $31-40$ & 3 & 2 & 7 & Manager & Information technology & Tokyo, 2010 & 54 \\
\hline
\end{tabular}




\begin{tabular}{|c|c|c|c|c|c|c|c|c|c|c|c|}
\hline J6 & Norway & Norway & Male & $31-40$ & 0 & 0 & 7 & Manager & Finance/insurance & Tokyo, 2010 & 45 \\
\hline $\mathrm{J} 7$ & Finland & Finland & Male & $20-30$ & 9 & 0 & 5 & Top manager & Wood and paper & Osaka, 2010 & 34 \\
\hline $\mathrm{J} 8$ & Denmark & Denmark & Male & $31-40$ & 6 & 3 & 6 & Top manager & Wood and paper & Tokyo, 2010 & 48 \\
\hline J9 & Finland & Finland & Male & $51-65$ & 5 & 0 & 10 & Top manager & Wood and paper & Tokyo, 2010 & 62 \\
\hline $\mathrm{J} 10$ & Finland & Finland & Male & $41-50$ & 2 & 2 & 14 & Top manager & Airline & Tokyo, 2010 & 57 \\
\hline $\mathrm{J} 11$ & Denmark & Denmark & Male & $51-65$ & 4 & 20 & 33 & Top manager & Machinery & Tokyo, 2010 & 75 \\
\hline $\mathrm{J} 12$ & Denmark & Denmark & Male & $51-65$ & 6 & 16 & 35 & Top manager & Machinery & Tokyo, 2010 & 80 \\
\hline $\mathrm{J} 13$ & Finland & Finland & Male & $31-40$ & 12 & 4 & 2 & Top manager & Information technology & Tokyo, 2010 & 57 \\
\hline $\mathrm{J} 14$ & Finland & Finland & Male & $51-65$ & 3 & 3 & 38 & Top manager & Electronics & Tokyo, 2011 & 42 \\
\hline $\mathrm{J} 15$ & Denmark & Denmark & Male & $31-40$ & 2 & 4 & 2 & Top manager & Information technology & Tokyo, 2011 & 34 \\
\hline $\mathrm{J} 16$ & Sweden & Sweden & Male & $51-65$ & 0 & 2 & 20 & Top manager & Shipping/logistics & Tokyo, 2011 & 34 \\
\hline $\mathrm{J} 17$ & Sweden & Sweden & Male & $41-50$ & 10 & 0 & 10 & Top manager & Healthcare & Tokyo, 2011 & 45 \\
\hline $\mathrm{J} 18$ & Sweden & Sweden & Male & $51-65$ & 14 & 8 & 25 & Top manager & Machinery & Tokyo, 2011 & 64 \\
\hline $\mathrm{J} 19$ & Sweden & Sweden & Male & $41-50$ & 4 & 4 & 15 & Manager & Pharmaceutical & Tokyo, 2011 & 70 \\
\hline $\mathrm{J} 20$ & Denmark & Denmark & Male & $51-65$ & 25 & 0 & 22 & Top manager & Pharmaceutical & Tokyo, 2011 & 54 \\
\hline $\mathrm{J} 21$ & Denmark & Denmark & Male & $41-50$ & 3 & 12 & 20 & Top manager & Machinery & Tokyo, 2011 & 62 \\
\hline $\mathrm{J} 22$ & Denmark & Denmark & Male & $41-50$ & 20 & 4 & 4 & Top manager & Shipping/logistics & Tokyo, 2011 & 45 \\
\hline $\mathrm{J} 23$ & Denmark & Denmark & Male & $31-40$ & 1 & 0 & 6 & Top manager & Pharmaceutical & Tokyo, 2011 & 70 \\
\hline $\mathrm{J} 24$ & Denmark & Denmark & Male & $31-40$ & 6 & 2 & 2 & Top manager & Wood and paper & Tokyo, 2011 & 35 \\
\hline $\mathrm{J} 25$ & Denmark & Denmark & Male & $41-50$ & 8 & 0 & 7 & Top manager & Food product & Tokyo, 2011 & 70 \\
\hline $\mathrm{J} 26$ & Sweden & Sweden & Male & $51-65$ & 20 & 0 & 8 & Top manager & Communication & Tokyo, 2011 & 67 \\
\hline $\mathrm{J} 27$ & Norway & Norway/Japan & Male & $20-30$ & 4 & 0 & 3 & Manager & Machinery & Tokyo, 2011 & 36 \\
\hline $\mathrm{J} 28$ & Sweden & Sweden & Male & $51-65$ & 8 & 0 & 1 & Top manager & Electronics & Tokyo, 2012 & 72 \\
\hline $\mathrm{J} 29$ & Sweden & Sweden & Male & $51-65$ & 2 & 18 & 28 & Top manager & Machinery & Tokyo, 2012 & 69 \\
\hline $\mathrm{J} 30$ & Norway & Norway & Male & $51-65$ & 36 & 4 & 2 & Top manager & Wood and paper & Tokyo, 2012 & 115 \\
\hline $\mathrm{J} 31$ & Sweden & Sweden & Male & $51-65$ & 6 & 3 & 35 & Top manager & Electronics & Tokyo, 2012 & 79 \\
\hline $\mathrm{J} 32$ & Sweden & Sweden & Male & $41-50$ & 5 & 2 & 5 & Top manager & Medical equipment & Tokyo, 2012 & 120 \\
\hline $\mathrm{J} 33$ & Norway & Norway & Male & $41-50$ & 2 & 2 & 8 & Manager & Shipping & Tokyo, 2012 & 48 \\
\hline $\mathrm{J} 34$ & Sweden & Sweden & Male & $41-50$ & 7 & 6 & 33 & Top manager & Machinery & Tokyo, 2012 & 56 \\
\hline $\mathrm{J} 35$ & Norway & Norway & Male & $31-40$ & 15 & 0 & 1 & Manager & Auto parts & Tokyo, 2012 & 45 \\
\hline $\mathrm{J} 36$ & Denmark & Denmark & Male & $41-50$ & 6 & 2 & 2 & Top manager & Shipping/logistics & Tokyo, 2012 & 65 \\
\hline $\mathrm{J} 37$ & Sweden & Sweden & Male & $31-40$ & 7 & 0 & 5 & Manager & Machinery & Tokyo, 2012 & 50 \\
\hline $\mathrm{J} 38$ & Denmark & Denmark & Male & $51-65$ & 2 & 6 & 30 & Top manager & Auto parts & Tokyo, 2012 & 57 \\
\hline J39 & Denmark & Denmark/Japan & Male & $31-40$ & 11 & 0 & 3 & Top manager & Food products & Tokyo, 2012 & 85 \\
\hline $\mathrm{J} 40$ & Sweden & Sweden & Male & $41-50$ & 20 & 3 & 1 & Top manager & Medical equipment & Osaka, 2012 & 80 \\
\hline $\mathrm{J} 41$ & Sweden & Sweden & Male & $51-65$ & 14 & 2 & 20 & Top manager & Machinery & Tokyo, 2012 & 65 \\
\hline
\end{tabular}




\begin{tabular}{|c|c|c|c|c|c|c|c|c|c|c|c|}
\hline $\mathrm{J} 42$ & Norway & Norway & Male & $41-50$ & 3 & 4 & 15 & Top manager & Finance & Tokyo, 2012 & 54 \\
\hline $\mathrm{J} 43$ & Norway & Norway & Male & $51-65$ & 6 & 6 & 20 & Top manager & Machinery & Tokyo, 2012 & 60 \\
\hline $\mathrm{J} 44$ & Norway & Norway & Male & $41-50$ & 11 & 4 & 3 & Top manager & Machinery & Tokyo, 2012 & 67 \\
\hline $\mathrm{J} 45$ & Sweden & Sweden & Male & $41-50$ & 8 & 0 & 20 & Top manager & Information technology & Tokyo, 2012 & 64 \\
\hline $\mathrm{J} 46$ & Norway & Norway & Male & $41-50$ & 1 & 4 & 9 & Manager & Shipping/logistics & Osaka, 2012 & 60 \\
\hline
\end{tabular}

Note: Code; $\mathrm{C}=$ China, $\mathrm{J}=$ Japan 
Table 2. Structure of data analysis for expatriate identities

\begin{tabular}{|c|c|c|c|}
\hline $\begin{array}{l}\text { Aggregate } \\
\text { dimensions }\end{array}$ & $\begin{array}{l}\text { Second-order } \\
\text { concepts }\end{array}$ & $\begin{array}{l}\text { First-order } \\
\text { concepts, } \\
\% \text { of examples }\end{array}$ & Interview examples, [sources] \\
\hline \multirow[t]{5}{*}{$\begin{array}{l}\text { Expatriate } \\
\text { identity }\end{array}$} & \multirow[t]{3}{*}{$\begin{array}{l}\text { Manager } \\
\text { identity }\end{array}$} & $\begin{array}{l}\text { Headquarters } \\
\text { representative } \\
{[79 \%(\text { China } 85 \% \text {, }} \\
\text { Japan } 76 \%)]\end{array}$ & $\begin{array}{l}\text { "My role here is to help the Chinese team to make the turn around. My experience from Finland can be } \\
\text { shared to help Chinese managers in this company to learn to look ahead and make the needed } \\
\text { changes... There are advantages of being a global company. Having global practices gives agility and } \\
\text { speed for the company. For example, I have recently recruited a finance control staff. I am making her } \\
\text { getting used to the common practices and processes that our company has [from headquarters]" [C1]. } \\
\text { "There is some rigidity in this Japanese system that is inhibiting growth and development [in this } \\
\text { foreign subsidiary]. My job is help them to change it...I came here to tell them how they [local } \\
\text { employees] need to behave" [J46]. }\end{array}$ \\
\hline & & $\begin{array}{l}\text { Power and control } \\
\text { [89\% (China } 96 \% \text {, } \\
\text { Japan } 84 \%)]\end{array}$ & $\begin{array}{l}\text { "I am part of our global operations management team. In my team [in China] I am the only foreigner. } \\
\text { Obviously, I have to say things and control [local employees]" [C3]. } \\
\text { "Working with Japanese is kind of kiss and kick. You have to kiss them to show that you are one } \\
\text { family, that we have harmony. But you have to kick them to do things. And you have to be very } \\
\text { specific in telling them what to do...I need to control them" [J22]. }\end{array}$ \\
\hline & & $\begin{array}{l}\text { Work centrality } \\
{[92 \%(\text { China } 96 \% \text {, }} \\
\text { Japan } 89 \%)]\end{array}$ & $\begin{array}{l}\text { "Even though I was very excited to move here, my decision was work driven" [C15]. } \\
\text { "I am a very direct person and like to move fast. Before coming here, I was in Saudi Arabia. Work is } \\
\text { more important to me than locations...I focus on increasing business volume in this subsidiary... work } \\
\text { is a very important part of me" [J15]. }\end{array}$ \\
\hline & \multirow[t]{2}{*}{$\begin{array}{l}\text { Foreigner } \\
\text { identity }\end{array}$} & $\begin{array}{l}\text { Privileged } \\
\text { foreigner }[79 \% \\
(\text { China } 96 \% \text {, Japan } \\
72 \%)]\end{array}$ & $\begin{array}{l}\text { "Chinese people adore foreigners. This is deep in their culture. This is something I just find weird. It's } \\
\text { weird. If you just show your Finnish passport, then you are superior. It shouldn't be an issue, but it is } \\
\text { like this" [C16]. } \\
\text { "I have an advantage being a Caucasian in Japan...they look up to us... Not being Japanese makes it } \\
\text { possible for me to do things that Japanese cannot do" [J25]. }\end{array}$ \\
\hline & & $\begin{array}{l}\text { Expatriate } \\
\text { community }[93 \% \\
(\text { China } 89 \% \text {, Japan } \\
96 \%)]\end{array}$ & $\begin{array}{l}\text { "On my free time I spent time with the Nordic business society. Many of my friends are foreigners" } \\
\text { [C13]. } \\
\text { "I moved to apartment next to another expatriate working in my company. I know that it is wrong but } \\
\text { we, expatriates have lunch and spend time off work together" [J42]. }\end{array}$ \\
\hline Cultural & National & National pride & "I never want to identify myself with anything else than Finland...I am a Finn and I will always be a \\
\hline
\end{tabular}




\begin{tabular}{|c|c|c|c|}
\hline \multirow[t]{4}{*}{ identity } & \multirow[t]{2}{*}{ identity } & $\begin{array}{l}{[60 \%(\text { China } 70 \%,} \\
\text { Japan } 54 \%)]\end{array}$ & $\begin{array}{l}\text { Finn" [C21]. } \\
\text { "If you collect } 10 \text { Swedish in a room and you have brainstorming, something happens. If you do the } \\
\text { same thing in Japan, nothing happens...I am very proud to be Swedish" [J41]. }\end{array}$ \\
\hline & & $\begin{array}{l}\text { Identity separation } \\
\text { /outsider mentality } \\
{[88 \%(\text { China } 89 \%} \\
\text { Japan } 87 \%)]\end{array}$ & $\begin{array}{l}\text { "I cannot understand fully the Chinese mentality...I can never understand as a foreigner, and non-Asian } \\
\text { foreigner. Maybe it's easier if people come from Korea, which is more or less similar in some ways" } \\
\text { [C23]. } \\
\text { "Japan is a closed country and Japanese people are close minded. Not very international. We try to } \\
\text { change them. If they don't respect you, it is not your problem" [J31]. }\end{array}$ \\
\hline & \multirow[t]{2}{*}{$\begin{array}{l}\text { Host country } \\
\text { identity }\end{array}$} & $\begin{array}{l}\text { Identity } \\
\text { assimilation }[79 \% \\
(\text { China } 96 \% \text {, Japan } \\
69 \%)]\end{array}$ & $\begin{array}{l}\text { "I feel more and more Chinese. I am somewhere in-between [Chinese and Finnish cultures]" [C17]. } \\
\text { "I am half Japanese. I was born and raised in Denmark. I have a Japanese mother. As a teenager, I used } \\
\text { to hate Japan. Now I am married to a Japanese [person] and have started to appreciate many things in } \\
\text { Japan" [J39]. }\end{array}$ \\
\hline & & $\begin{array}{l}\text { Social segregation } \\
{[93 \%(\text { China } 89 \% \text {, }} \\
\text { Japan } 96 \%)]\end{array}$ & $\begin{array}{l}\text { "Waiguoren [foreigner in Mandarin Chinese] are foreigners. Chinese people keep a distance from you. } \\
\text { Waiguoren are not getting too much special attention. Nowadays if you to the bar area in the city, you } \\
\text { can see that there are Chinese people who are willing to pick up a fight with foreigners just to show that } \\
\text { they can beat up foreigners. [C5] } \\
\text { "I am a foreigner in Japan. I mean, I will never be a Japanese. Because I am a foreigner, I am told [by } \\
\text { the Japanese] that I will never understand Japan" [J25]. }\end{array}$ \\
\hline
\end{tabular}

Note. The attributions following quotations indicate denomination and a code for each interviewed expatriate. 
Table 3. Structure of data analysis for expatriate identity stability/change

\begin{tabular}{|c|c|c|}
\hline $\begin{array}{l}\text { Aggregate } \\
\text { dimension }\end{array}$ & $\begin{array}{l}\text { First-order } \\
\text { concepts, } \\
\% \text { of examples }\end{array}$ & Interview examples, [sources] \\
\hline \multirow[t]{2}{*}{ Identity stability } & $\begin{array}{l}\text { Work-related } \\
\text { identity verification } \\
{[93 \%(\text { China } 96 \% \text {, }} \\
\text { Japan } 90 \%)]\end{array}$ & $\begin{array}{l}\text { "I work closely with three Swedes, but otherwise everyone is Chinese in our department... Sometimes things } \\
\text { happen at work and I don't see it as a rational decision... I talk about it with my Swedish manager who is also in } \\
\text { the office here. I think we have the same perception why this is happening. Sometimes we get the feeling that } \\
\text { someone is covering up for their own mistakes, so that they don't tell the truth...Instead of working for the best of } \\
\text { our company, they work for their own interests" [C15]. } \\
\text { "I came here from the States. The point being that somewhere along the line there are some thing that I can bring, } \\
\text { there are some things I might even take out here and take back to the States. Because the guy who succeeded me in } \\
\text { the States is a good friend. We keep the dialogue. He was a divisional marketing manager when I was in Korea. } \\
\text { We also worked in Belgium together...discussions with him help me to stay on the right track" [J22]. }\end{array}$ \\
\hline & $\begin{array}{l}\text { Non-work identity } \\
\text { verification }[69 \% \\
(\text { China } 85 \% \text {, Japan } \\
56 \%)]\end{array}$ & $\begin{array}{l}\text { "We [me and my wife] live in a bubble with Finns only. The social contacts we have are mostly foreigners. We go } \\
\text { to dinner with friends who are mostly foreigners. Most of them are Finns, but I also have Brazilian, American } \\
\text { friends, so foreigners only... I don't know a single expatriate who would have a Chinese friend he or she has found } \\
\text { outside the work place. I don't know a single person who has been invited to the home of a Chinese colleague...I } \\
\text { hope I haven't become more Chinese, because I still respect Finnish values much more such as honesty" [C5]. } \\
\text { "I have given up. Why should I understand everything? This is not my country or system. I like to hang around } \\
\text { with other expatriates because we share similar values and opinions" [J46]. }\end{array}$ \\
\hline \multirow[t]{2}{*}{ Identity change } & $\begin{array}{l}\text { Work-related } \\
\text { identity disruption } \\
{[93 \% \text { (China } 96 \% \text {, }} \\
\text { Japan 90\%)] }\end{array}$ & $\begin{array}{l}\text { "[After six years in China], I have changed my way of doing things. You get used to things. If everyone around me } \\
\text { does it this way, I would do the same. I wouldn't think too much. For example, many things are very flexible in } \\
\text { China. In the beginning, I was very scared all flexibility in the company as such flexibility would be a potential } \\
\text { risk" [C10]. } \\
\text { "I was so impatient and wanted so many changes to happen immediately. I made a lot of wrong decisions. But they } \\
\text { [local employees] never said that this would not work. I had to find out by myself. I have learned from experience } \\
\text { that everything I do here should be done very gradually if I want to have success. It takes more time to implement } \\
\text { changes" [J18]. }\end{array}$ \\
\hline & $\begin{array}{l}\text { Non-work identity } \\
\text { disruption }[80 \% \\
\text { (China } 88 \% \text {, Japan } \\
76 \%)]\end{array}$ & $\begin{array}{l}\text { "When you spend more time in different cultures like I spent here, you learn more about this culture. And you } \\
\text { learn also things that you don't like. The same thing happens for me when I work outside Finland... Actually, I } \\
\text { start to see more and more Finns that I don't like" [C11]. } \\
\text { "In the beginning I did many things completely wrong because I came here with my Western values and } \\
\text { assumptions. I was so frustrated. But I woke up because of this clash of cultures and understood that I was a part of }\end{array}$ \\
\hline
\end{tabular}


\begin{tabular}{|l|l|l|}
\hline & & the problem" [J23].
\end{tabular}

Note. The attributions following quotations indicate denomination and a code for each interviewed expatriate.

Table 4. Structure of data analysis for expatriate adjustment

\begin{tabular}{|c|c|c|}
\hline $\begin{array}{l}\text { Aggregate } \\
\text { dimension }\end{array}$ & $\begin{array}{l}\text { First-order } \\
\text { concepts, } \\
\% \text { of examples }\end{array}$ & Interview examples, [sources] \\
\hline \multirow[t]{2}{*}{$\begin{array}{l}\text { Mode of } \\
\text { adjustment }\end{array}$} & $\begin{array}{l}\text { Mode of work } \\
\text { adjustment }[95 \% \\
(\text { China } 96 \% \text {, Japan } \\
92 \%)]\end{array}$ & $\begin{array}{l}\text { "It is using power and control. Obviously, you have to say things, and then you grab control and leave somebody } \\
\text { out" [C3]. } \\
\text { "In the past, [local] sales managers were making all decisions. That is very much tradition in Japan. I mean, you } \\
\text { are not making any decisions; the guy above you make all decisions. I do it in a completely different way" [J3]. }\end{array}$ \\
\hline & $\begin{array}{l}\text { Mode of non-work } \\
\text { adjustment }[91 \% \\
\text { (China } 92 \% \text {, Japan } \\
86 \% \text { )] }\end{array}$ & $\begin{array}{l}\text { "We [me and my wife] chose to live in Central Park [an expatriate residence area in central Beijing]. We knew it } \\
\text { was going to take a while before we got any flat there, but still we would like to live there... It's very nice and } \\
\text { westernized. Being here we don't feel that we are in Beijing, or at least in the traditional Beijing." [C15] } \\
\text { "During major national celebrations, like Christmas, I return back to Sweden or have Christmas parties with other } \\
\text { Swedish expatriates. I don't celebrate Japanese national celebrations at all" [J3]. }\end{array}$ \\
\hline \multirow[t]{2}{*}{$\begin{array}{l}\text { Degree of } \\
\text { adjustment }\end{array}$} & $\begin{array}{l}\text { Degree of work } \\
\text { adjustment }[93 \% \\
\text { (China } 96 \% \text {, Japan } \\
90 \%)]\end{array}$ & $\begin{array}{l}\text { "I don't follow the rules so much anymore [unlike in Finland] ... I don't see any more that it is so important that } \\
\text { everything is followed in the same way as in Helsinki... I know it's very frustrating [to Finns at headquarters], but } \\
\text { people here [the Chinese] still want to reach good target and outcome. The way how to get there [targets] is } \\
\text { different" [C4]. } \\
\text { "I did not connect very well with the Japanese management or with the Japanese in general. It was not their fault, it } \\
\text { was mine because I looked at my assignment of being here for five years and all my effort was concentrated to get } \\
\text { this company somehow off the ground. I did not realize that I was not able to connect with them very well. Once I } \\
\text { was finally able to realize this, I realized that communication and learning a bit more every day after waking up } \\
\text { and going back to sleep was to get some knowledge of this country, people, language, and business practices. Once } \\
\text { I got a bit of that under my belt, then things started to change. Then I was able to communicate with people, I could } \\
\text { walk in the factory and talk to the people" [J44]. }\end{array}$ \\
\hline & $\begin{array}{l}\text { Degree of } \\
\text { non-work } \\
\text { adjustment }[69 \% \\
(\text { China } 85 \% \text {, Japan } \\
56 \%)]\end{array}$ & $\begin{array}{l}\text { "I have lived in China for a long time. In terms of my way of values and thinking, one tiny specific detail is that I } \\
\text { drink hot water occasionally which for Finnish people sounds very weird...I think many of my attitudes have } \\
\text { changed...Maybe it's has to do with [me being] sympathetic to Chinese thinking to some extent...I get more and } \\
\text { more Chinese" [C17]. } \\
\text { "I had to change my behavior when I came here. It has helped me a little bit [to adjust]. I am now less frustrated } \\
\text { when I interact with Japanese" [J9]. }\end{array}$ \\
\hline
\end{tabular}

Note. The attributions following quotations indicate denomination and a code for each interviewed expatriate. 
Figure 1. An identity model of corporate expatriate adjustment

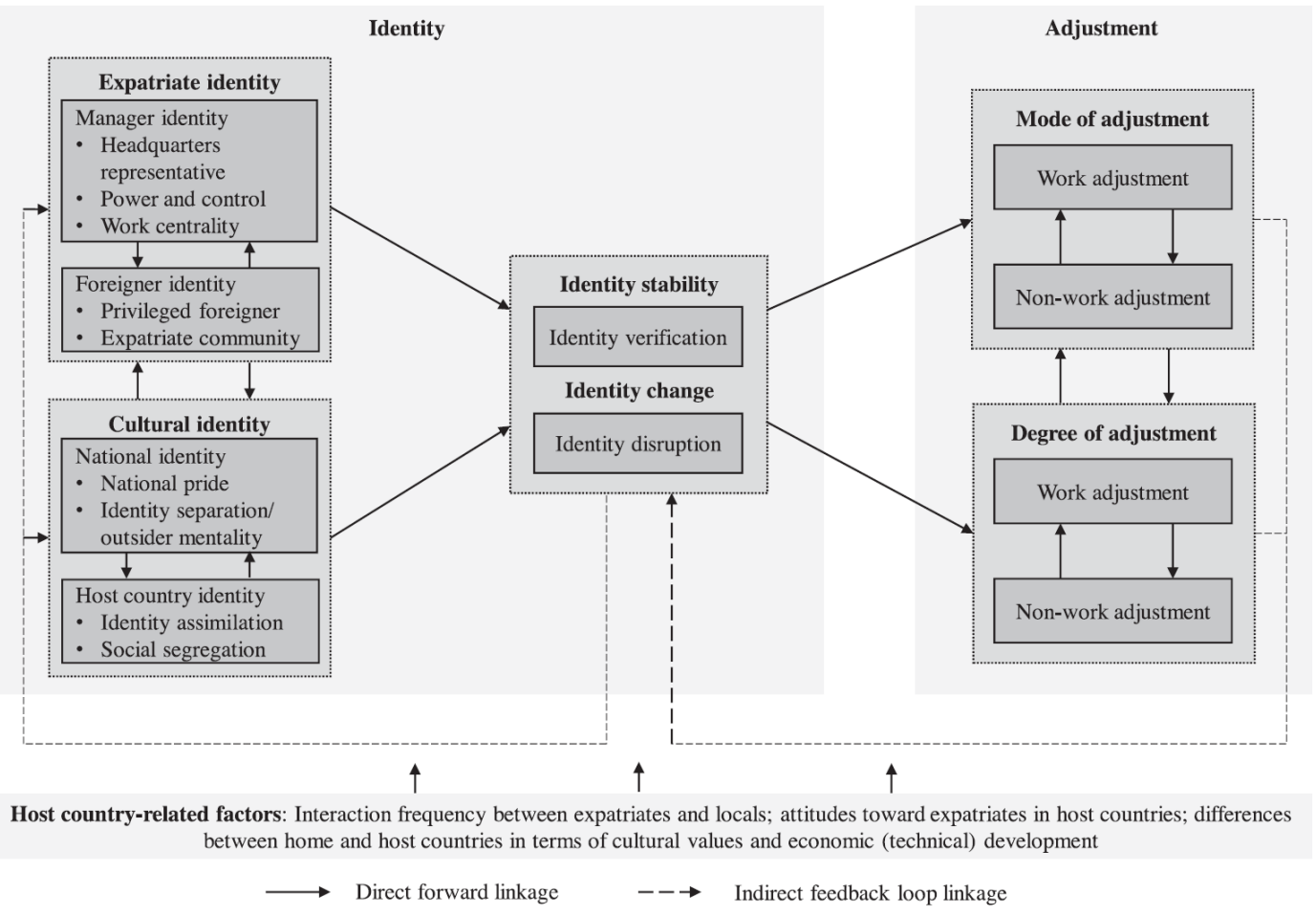

Fig. 1. An identity model of corporate expatriate adjustment. 